\title{
Pathophysiological Roles of Abnormal Axon Initial Segments in Neurodevelopmental Disorders
}

\author{
Masashi Fujitani *, Yoshinori Otani and Hisao Miyajima
}

check for updates

Citation: Fujitani, M.; Otani, Y.; Miyajima, H. Pathophysiological Roles of Abnormal Axon Initial Segments in Neurodevelopmental Disorders. Cells 2021, 10, 2110.

https://doi.org/10.3390/cells10082110

Academic Editors: Koh-ichi Nagata and Orly Reiner

Received: 27 July 2021

Accepted: 15 August 2021

Published: 17 August 2021

Publisher's Note: MDPI stays neutral with regard to jurisdictional claims in published maps and institutional affiliations.

Copyright: (c) 2021 by the authors. Licensee MDPI, Basel, Switzerland. This article is an open access article distributed under the terms and conditions of the Creative Commons Attribution (CC BY) license (https:// creativecommons.org/licenses/by/ $4.0 /)$.
Department of Anatomy and Neuroscience, Faculty of Medicine, Shimane University, 89-1 Enya-cho, Izumo-shi 693-8501, Shimane, Japan; yotani@med.shimane-u.ac.jp (Y.O.); miyajima@med.shimane-u.ac.jp (H.M.)

* Correspondence: fujitani@med.shimane-u.ac.jp; Tel.: +81-853-20-2108; Fax: +81-853-20-2105

\begin{abstract}
The 20-60 $\mu \mathrm{m}$ axon initial segment (AIS) is proximally located at the interface between the axon and cell body. AIS has characteristic molecular and structural properties regulated by the crucial protein, ankyrin-G. The AIS contains a high density of $\mathrm{Na}^{+}$channels relative to the cell body, which allows low thresholds for the initiation of action potential (AP). Molecular and physiological studies have shown that the AIS is also a key domain for the control of neuronal excitability by homeostatic mechanisms. The AIS has high plasticity in normal developmental processes and pathological activities, such as injury, neurodegeneration, and neurodevelopmental disorders (NDDs). In the first half of this review, we provide an overview of the molecular, structural, and ion-channel characteristics of AIS, AIS regulation through axo-axonic synapses, and axo-glial interactions. In the second half, to understand the relationship between NDDs and AIS, we discuss the activity-dependent plasticity of AIS, the human mutation of AIS regulatory genes, and the pathophysiological role of an abnormal AIS in NDD model animals and patients. We propose that the AIS may provide a potentially valuable structural biomarker in response to abnormal network activity in vivo as well as a new treatment concept at the neural circuit level.
\end{abstract}

Keywords: axon initial segment (AIS); action potential (AP); ankyrin-G; spectrins; plasticity; neurodevelopmental disorders (NDDs)

\section{Introduction}

Neurons generally possess several primary features. The cell body contains the nucleus and gives rise to two types of processes: axons and dendrites. Axons are the action potential (AP)-transmitting element of neurons, and the AP is initiated at the initial segment of the axon (AIS) and propagates to the synapse. In myelinated axons, the AP is regenerated at the nodes of Ranvier, with small gaps in the myelin sheath. $\mathrm{Na}^{+}$channels are located at high density in the AIS, as well as at the nodes of Ranvier (Figure 1). In addition to regulating AP initiation, the AIS maintains axon-dendrite polarity [1-4]. To focus on the physiological and pathological excitability-dependent plastic change of the AIS structure, we mainly emphasize the role of the AIS in AP initiation in this review rather than polarity regulation.

The AIS of a neuron comprises the proximal 20-60 $\mu \mathrm{m}$ at the interface between the axon and cell body. Palay and Peters first described the characteristic structures using electron microscopy [5,6]. The internal structure of the AIS is characterized by specific features segregated from the axon hillock and neuronal cell body. Interestingly, different types of neurons have distinct AIS locations, AIS lengths, and ion channel properties $[7,8]$. It is well accepted that the density of the $\mathrm{Na}^{+}$channels is higher in the AIS than in the body. The AIS is not only the beginning of the axon, but also a key domain in the control of neuronal excitability [9-11].

In this review, we first summarize the molecular, structural, ion-channel characteristics, and cell-cell interactions of the AIS. We then describe the activity-dependent plasticity of AIS, primarily by developmental activity. To link the physiological and pathological 
roles of the AIS in neurodevelopmental disorders (NDDs), we investigate recent advances in human mutation studies of AIS regulatory genes that are highly related to NDDs. The anatomical properties of AIS can be plastic in response to pathological activity; therefore, we discuss recently discovered abnormal pathophysiological changes in the AIS in NDDmodel animals and human patients with NDDs. Future studies of the AIS may provide potentially valuable tools for determining the structural and functional neuronal plasticity in response to abnormal network activity in vivo.
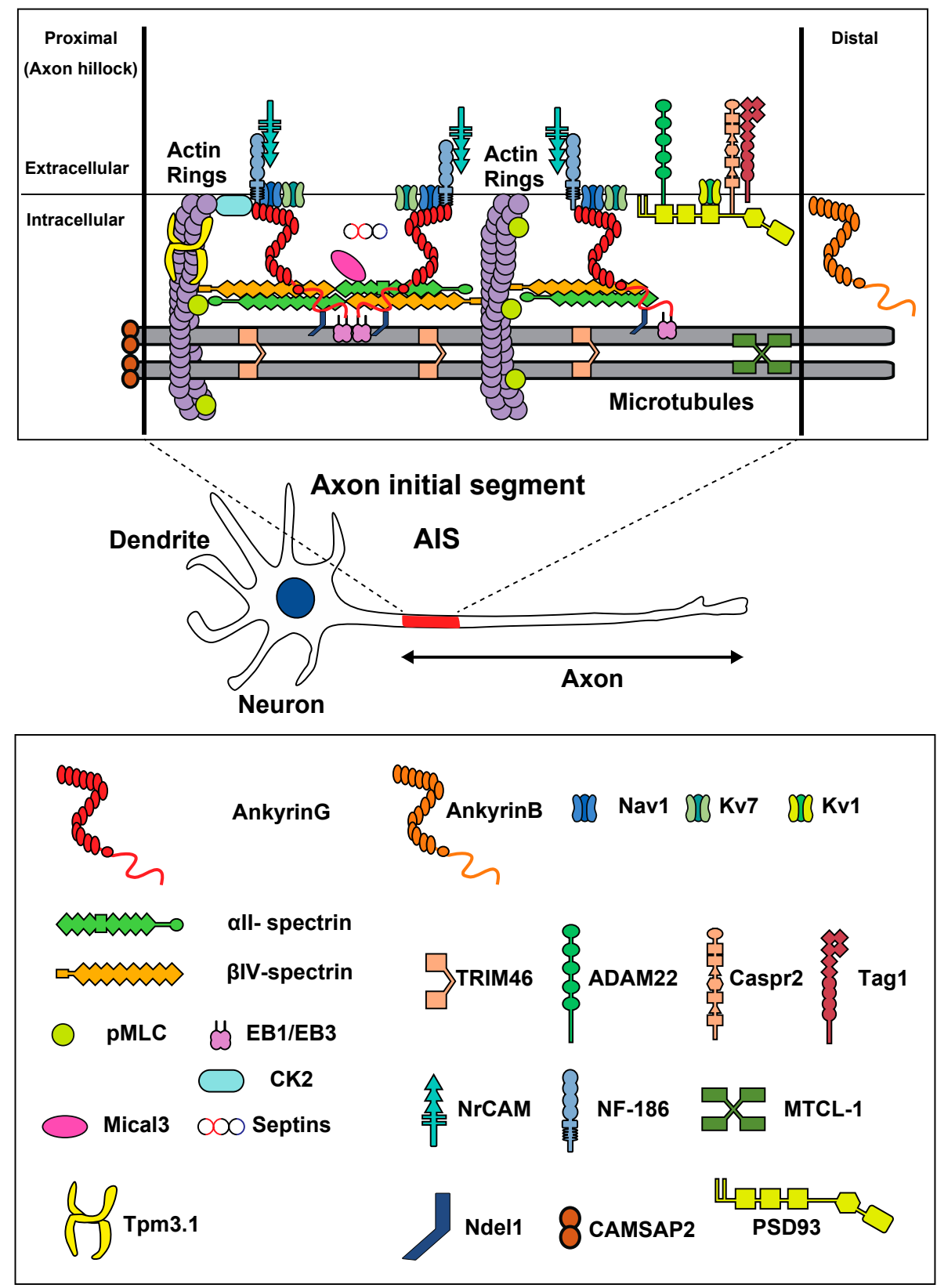

Figure 1. Molecular organization of the AIS, and diagram of a multipolar neuron. Membrane proteins (Nav/Kv7 channels, NF-186, NrCAM) are anchored by ankyrin-G (red). Ankyrin-G is inserted into the $\alpha \mathrm{II}$ (green) / $\beta \mathrm{IV}$ (orange) spectrin tetramers. Actin rings (purple) are connected with spectrin tetramers. In the distal part, Kv1 channels, ADAM22, Tag1, and Caspr2 are present. Ankyrin-G binds to microtubules via EB1/EB3 proteins and Ndel1. Bundles of microtubules are crosslinked by TRIM46 and MTCL-1. Actin rings appear as twisted ropes possessing two long, intertwined actin filaments connected by a dense mesh of aligned spectrins. CK2, MLC, and Tpm 3.1 bind to actin rings. Mical3 and septins are present at the AIS and control the AIS structure. 


\section{Molecular Characteristics of the AIS}

The AIS, 20-60 $\mu \mathrm{m}$ in length, is located at the proximal interface between the axon and cell body. Many studies have shown that the AIS contains a wide array of proteins, including microtubules and the plasma membrane (Figure 1) [1-4]. Among these, ankyrinG (ANK3), a neuron-specific protein located at the AIS and nodes of Ranvier, is thought to be the most critical component of the scaffold structure of the AIS.

Ankyrin-G has a membrane-binding domain at the N-terminus, as well as a spectrinbinding domain, a serine-rich domain, and a C-terminal domain [3]. Ankyrin-G has two main isoforms, 270 and $480 \mathrm{kDa}$, respectively, that are the major isoforms specifically localized at the AIS and nodes of Ranvier $[12,13]$. Shortly after axon specification, ankyrin$\mathrm{G}$ begins to cluster, recruiting AIS components, such as spectrin tetramers, at the proximal axon $[14,15]$. Most AIS protein components interact with ankyrin-G either directly or indirectly, and knockdown or knockout of ankyrin-G completely disrupts the localization of AIS proteins [16-18]. Therefore, ankyrin-G has been proposed as a master regulator of the AIS structure and polarity [1-4].

In addition to ankyrin-G, spectrins are essential components of the AIS structure. Spectrin tetramers consisting of two $\alpha$ and two $\beta$ subunits are widely expressed in neurons. Vertebrate axons possess $\alpha$-spectrin and five types of $\beta$ spectrins: $\beta \mathrm{I}-\beta \mathrm{V}$ [19]. Spectrin tetramers contain the $\beta I V$ spectrin subunit at the AIS and nodes of Ranvier (Figure 1) [20]. The $280 \mathrm{kDa}$ full-length isoform of $\beta I V-s p e c t r i n$ contains an actin-binding domain, 17 triple-helical spectrin repeats, and a specific pleckstrin-homology domain [3]. Recently, the $\alpha$ II-spectrin subunit has been identified as the partner of the $\beta I V-s p e c t r i n$ at the AIS and nodes of Ranvier [21,22]. Spectrin tetramers link adjacent actin rings, as shown in Figure 1. Knockout of $\alpha$ II-spectrin results in embryonic lethality as well as cardiac, craniofacial, and neural tube malformations in the embryo [23]. The conditional deletion of $\alpha$ II-spectrin leads to the disruption of the AIS structure; therefore, $\alpha$ II-spectrin is also an important AIS protein, even though it is expressed throughout neurons, rather than only in the AIS [22,24]. Similarly, the loss of $\beta I V$-spectrin in the brain induces disruption of the AIS structure in vivo [25].

This modular structure allows ankyrin-G to organize the AIS scaffold (Figure 1) [3]. It anchors AIS-specific membrane proteins, including voltage-gated sodium (Nav) and potassium (Kv) channels, initiating AP (Figure 1). Ankyrin-G knockdown prevented the localization and clustering of AIS proteins, including sodium channels [16-18].

As described in Section 4 below, the major subtypes of $\mathrm{Na}^{+}$channels at the AIS are Nav 1.1, 1.2, and 1.6 [9-11]. In addition, $\mathrm{K}^{+}$channels at the AIS are also important for modulating the AP. Kv7.2 and Kv7.3 (KCNQ2/3) channels can form homomeric or heteromeric complexes and accumulate at the AIS without binding to ankyrin-G [9-11].

Conversely, the mechanism of ankyrin-G clustering at the AIS is strongly related to the complex of Ankyrin-B, $\alpha$ II-spectrin, and $\beta$ II-spectrin. This complex excludes ankyrin-G from the distal axon, confining it to the proximal axon [15]. Neuronal polarity and the developmental process of the AIS is well discussed in an excellent review [26]. The dynein regulator Ndel1 was also stably anchored at the AIS by its interaction with ankyrin-G. Ndel1 activates the retrieval of vesicles transported by dynein in the AIS [27].

Additionally, two cell adhesion molecules, neurofascin 186 (NF-186) and NrCAM, were found to exist in the AIS; however, an initial study showed that these adhesion molecules are not necessary for Nav channel clustering [18,28]. Recent studies have also shown that NF-186 is not required for AIS assembly, but is required for AIS maintenance in vivo [29]. Other studies have also shown that NF-186 knockdown induces AIS structural abnormalities $[30,31]$. Therefore, further investigation is necessary to fully understand the molecular functions of NF-186.

Among microtubule-associated proteins, the C-terminus of ankyrin-G connects to microtubules via interactions with EB1/3. EB3 knockdown alters Nav localization [32]. TRIM46 was shown to be uniquely enriched in the proximal AIS and does not regulate AIS maintenance [33] (Figure 1). Cerebellar Purkinje cell-specific microtubule cross-linking 
factor 1 (MTCL1) knockout mice exhibit the loss of axonal polarity and mislocalization of ankyrin-G [34].

In addition to these proteins, several other adhesion molecules, such as Tag1, Caspr2, and disintegrin and metalloproteinase domain-containing protein 22 (ADAM22), have been shown to localize in the distal AIS, although no knockout mice studies of these molecules have demonstrated disruption of the AIS compartment [35].

Among actin-associated proteins, CK2 (Casein kinase2), the actin ring-related proteins, myosin light chain (MLC), and tropomyosin (Tpm) 3.1 are important for AIS structural maintenance [36-38]. Recent studies have also shown that Mical3 (microtubule associated monooxygenase, calponin, and LIM domain containing 3), an oxidoreductase that depolymerizes F-actin, colocalizes with spectrins in the insoluble fraction of AIS, regulating the AIS assembly transiently and via actin patches [39]. The same research team also showed that septins, small GTP binding proteins, are also localized in the insoluble fraction of the AIS, and that knockdown of septins induces the disruption of the AIS assembly [39].

Ultimately, these results show that regulatory proteins for microtubules and the actin cytoskeleton and AIS-specific components, such as ankyrin-G or spectrins, are all important components in the regulation of the structure of the AIS.

\section{Structural Characteristics of the AIS}

Palay and Peters initially described the characteristic structure of the AIS using electron microscopy $[5,6]$. The internal structure of the AIS is characterized by three special features: (a) scattered clusters of ribosomes, $(b)$ a dense layer of fine granular material beneath the plasma membrane, and (c) fascicles of microtubules.

Subsequent investigations using a super-resolution imaging method, called stochastic optical reconstruction microscopy (STORM), have shown the unique structure of the axon [40]. Actin forms ring-like structures wrapped around the surface of the axons. These rings are evenly spaced every $190 \mathrm{~nm}$. This structure is not observed in dendrites [40]. In the AIS, a periodic assembly of actin rings, $\beta I V$-spectrin, and ankyrin-G have been observed [41,42].

Simultaneously, the actin structure in the AIS has been shown using platinum replica electron microscopy (PREM). In the center of the AIS cytoskeleton exist bundles of microtubules coated with a dense, fibrillar-globular actin [43]. Immunogold PREM has shown that the actin coat contains AIS proteins such as neurofascin, NrCAM, or Nav [43].

Finally, a 2019 study by Vassilopoulos et al. unroofed the dorsal part of cultured neurons and used PREM and STORM to observe that the actin rings are likely to be in the form of twisted ropes containing two long, intertwined actin filaments connected by a dense mesh of aligned spectrins [44]. As discussed in their 2021 review article, similar techniques conducted without unroofing the dorsal part of neurons will help us to understand the structure of whole actin rings at the ultrastructural level [45].

\section{Ion Channel Properties of the AIS}

Physiological studies have shown direct evidence that APs are initiated at the distal end of the AIS in many types of neurons [9-11]. It has also become clear that the AIS is not simply a trigger zone for AP generation but also plays a key role in regulating the integration of synaptic inputs, intrinsic excitability, and transmitter release, as has been intensively discussed [9-11].

$\mathrm{Na}^{+}$channels are involved in the rapid depolarization of APs. Of the four $\mathrm{Na}^{+}$channel $\alpha$-subunits (Nav 1.1, Nav 1.2, Nav 1.3, and Nav 1.6) expressed in the brain, three subtypes (Nav 1.1, Nav 1.2, and Nav 1.6) are localized in the AIS according to their developmental diversity. Immunocytochemical studies have shown that the major $\mathrm{Na}^{+}$channel isoform in the AIS of adult CNS neurons is Nav $1.6[46,47]$. Interestingly, a tight coupling of $\mathrm{Na}^{+}$ channels to the actin cytoskeleton was found to prevent access to the $\mathrm{Na}^{+}$channels in the AIS by the patch-clamp technique [48]. Furthermore, a method was established to unbiasedly match the properties of a wide range of APs in a morphologically realistic 
model to accurately determine the distribution of $\mathrm{Na}^{+}$channels [48]. Using this approach, the number of $\mathrm{Na}^{+}$channels in the hippocampal pyramidal neuronal AIS was estimated to be 50 times greater than that in the cell body [48], but only five times greater than that in dentate granule cells [49]. In addition to their high density, the properties of $\mathrm{Na}^{+}$ channels in the AIS are unique, probably because they facilitate the initiation of APs in the AIS [9-11].

$\mathrm{K}^{+}$channels are essential for AP repolarization and play a role in setting the AP threshold, interspike intervals, and firing frequencies [9-11]. The predominant $\mathrm{K}^{+}$channel in the AIS of most neurons is the low-threshold Kv1 subtype [9-11]. Most neurons possess both Kv 1.1 and $\mathrm{Kv} 1.2$ in the AIS [9-11]. Direct patch-clamp recording from the AIS showed a high density of dendrotoxin (DTX)-sensitive, fast-activating, slow-inactivating Kv1-type $\mathrm{K}^{+}$currents in the AIS of cortical pyramidal neurons [9-11]. In addition, the distal part of the AIS of pyramidal neurons contains a high density of Kv 7.2 and Kv 7.3 (KCNQ2/3) channels [9-11].

Taken together, these data indicate that the expression patterns of different ion channels in the AIS are highly cell-specific.

\section{Non-Cell-Autonomous AIS Regulation through Axo-Axonic Synapse and Axo-Glial Interactions}

To the best of our knowledge, the only neurotransmission at the AIS through ligandgated ion channels uses $\gamma$-aminobutyric acid type A receptors (GABA $R$ s) [50]. GABA Rs containing $\alpha 2$ subunits ( $\left.\alpha 2-G_{A B A} R s\right)$ are specifically enriched in the AIS [50]. The AISs of the pyramidal cells of the forebrain contain inhibitory synapses that are exclusively innervated by chandelier cells (ChCs) [51,52]. Hines et al. showed that the localization of $\alpha 2-G_{A B A}$ Rs to the AIS is essential for the inhibitory control of pathological excitation [53].

The axons of ChCs are highly branched and characterized by arrays of vertically oriented terminals called cartridges, each of which holds synaptic connections [54]. Tai et al. found that the L1 family member L1CAM is required for ChC AIS innervation and maintenance [55]. Selective innervation of the pyramidal neuron AIS by ChCs requires the anchoring of L1CAM to the AIS by the cytoskeletal ankyrin-G/ $\beta$ IV-spectrin complex [54].

More recently, Pan-Vazquez et al. found, by in vivo imaging, that $\mathrm{ChC}$ axons and their axo-axonic synapses develop rapidly in infant mice from postnatal day (P)12 to P18 [56]. They also found that an increasing network activity during this period reduces the number of axo-axonic synapses and that the AIS length changes slightly [56]. In older mice (P40-P46), when ChC synapses switch to inhibitory, they result in an increase in axo-axonic synapses. The depolarizing nature of axo-axonic synapses suggests that this plasticity is homeostatic. In addition, increasing ChC activity may decrease the AIS length of pyramidal neurons that are connected to activated ChCs [56].

In glial cells, Rasband et al. reported an interesting interaction between microglia and the AIS [57]. Microglia are immune cells that reside in the brain and are actively involved in the regulation of neuronal excitability and function. Rasband et al. found that in the cerebral cortex, a subset of microglia spatially extended a single process that binds to the AIS. The interaction between microglia and AISs appears early in development and persists into adulthood. However, these interactions are reduced after brain injury due to the activation of microglia [57]. Recently, in a hypoglossal nerve injury model, Tamada et al. observed microglia-AIS interaction and the accumulation of mitochondria in the AIS after injury [58].

Astrocytes, the most abundant cells in the CNS, promote synapse formation and help refine neural connectivity. Molofsky et al. showed that the loss of astrocyte-encoded semaphorin Sema-3a leads to a dysregulated $\alpha$-motor neuron AIS orientation [59].

Lastly, regarding oligodendrocytes, cuprizone treatment increases axonal excitability in dysmyelinated mouse brains. Membrane repolarization and energy expenditure may be affected by the general misalignment of ion channels in the AIS [60]. The AIS of demyelinated axons begins closer to the cell body than in myelinated axons, but the expression of ankyrin G, $\beta I V$-spectrin, and ion channels was maintained [60]. Another 
study replicated this result using a genetic demyelination model [61]. These results suggest that myelination by oligodendrocytes is important for the maintenance of the AIS by the inhibition of the hyperexcitability of pyramidal neurons.

Taken together, these results indicate that the AIS can be controlled either in a cellautonomous fashion or in a non-cell-autonomous fashion.

\section{Activity-Responding Plasticity of AIS in Development and Disease Models}

Different types of neurons differ in the location, length, and ion channel configuration of the AIS $[1,2,11,62]$. Recent studies have shown that the structural properties of the AIS are plastic in response to normal developmental and pathological activities $[1,2,11,62]$. Since other rapid inhibitions of electrical properties of the neuronal AIS in vitro are welldocumented $[63,64]$, this review focuses on the plastic changes of the AIS in vivo.

Kuba et al. strikingly showed that the AIS in chicken nucleus magnocellularis neurons increased after deprivation of auditory inputs and moved closer to the cell body [65]. Physiological recordings also showed that these cells become more excitable [65]. The same research team recently reported that the regulation of cytoskeletal reorganization and sodium channel enrichment in the AIS differ depending on tonotopy (the spatial arrangement of sound frequency processing in the brain), but act synergistically in the auditory nucleus [66]. These results indicate that neurons adapt to presynaptic activity and maintain neural circuit homeostasis by altering the properties of the AIS.

Expanding evidence of the structural changes and remodeling of the AIS has been observed in disease models, such as type 2 diabetes [67], epilepsy [68], cerebral infarction [69], neuroinflammation by LPS [70], traumatic brain injury [71], Alzheimer's disease [72], amyotrophic lateral sclerosis [73] and mutations in the Tau gene causing frontotemporal dementia [74]. We will discuss these observations at length in Section 8.

In addition to these studies, cortical neurons undergo dynamic changes in the AIS in the visual cortex during the critical period of visual system development [75]. However, these changes were prevented by visual deprivation for postnatal weeks [75]. Gutzmann et al. also showed the relationship between the cisternal organelle (CO) and the AIS during visual cortex development. Synaptopodin-deficient mice lack COs and showed a shortening of the AIS in the dark for three to five weeks [76]. Another study showed an observed structural plasticity of the AIS in response to various auditory experiences at varying mouse ages [77].

More interestingly, long-term sensory deprivation altered the AIS length of layer II/III pyramidal neurons in the sensory cortex, and the same cortical neurons rapidly decreased the AIS length in an enriched environment [78]. In addition to visual and somatosensory deprivation, Galliano et al. showed that odor deprivation by naris occlusion produced AIS shortening and a decrease in intrinsic excitability in axon-bearing dopaminergic neurons in the glomerular layer of olfactory bulbs [79].

Taken together, these results suggest that bidirectional activity-dependent remodeling of the AIS by various types of sensory inputs plays a role in homeostatic adaptation in vivo.

\section{Association and Mutation Studies on AIS-Related Genes}

Molecular studies have shown the importance of AIS proteins, and clinical studies have shown that mutations in AIS regulatory genes are highly related to the etiology of neurodevelopmental disorders.

In general, the Diagnostic and Statistical Manual of Mental Disorders (DSM-5) states that neurodevelopmental disorders (NDDs) include intellectual disability (ID), communication disorders, autism spectrum disorder (ASD), attention deficit hyperactivity disorder (ADHD), specific learning disorder, and motor disorders [80]. However, NDDs are complex conditions [81]; therefore, this review broadly covers various classes of central nervous system (CNS) disorders that manifest during development, such as epilepsy, mood disorders, and schizophrenia.

Among the many AIS-localized proteins, as shown in Table 1, we focus on three genes: ANK-3, which encodes human ankyrin-3 protein (also known as ankyrin-G), SPTAN1, 
which encodes spectrin alpha chain, non-erythrocytic 1 protein, and SPTBN4, which encodes spectrin beta chain, non-erythrocytic 4 protein. Ion channel mutations that cause channelopathy are well described in excellent reviews [82,83].

Table 1. Mutations of ANK-3, SPTAN1, SPTBN4, and related symptoms.

\begin{tabular}{|c|c|c|c|c|}
\hline $\begin{array}{c}\text { Gene Name } \\
\text { Accession \# } \\
\text { (Chromosome \#) }\end{array}$ & Gene Mutation Locus & Mutated Protein & Symptoms & References \\
\hline \multirow{7}{*}{$\begin{array}{c}\text { ANK-3 } \\
\text { NM_020987.3 } \\
(10 q 21)\end{array}$} & $\begin{array}{l}\text { c. } 4705 \mathrm{~T}>\mathrm{G} \\
\text { c. } 11159 \mathrm{C}>\mathrm{T}^{*} \\
\text { c. } 12763 \mathrm{~A}>\mathrm{C}^{*}\end{array}$ & $\begin{array}{l}\text { p.S1569A } \\
\text { p.T3720M } \\
\text { p.T4255P }\end{array}$ & ASD & Bi et al., 2012 \\
\hline & c.11068G > A & p.G3690R & & Shi et al., 2013 \\
\hline & $\begin{array}{l}\text { 46,XY,t(2;10)(q11.2;q21.2) } \\
\text { c.10995delC }\end{array}$ & p.T3666LfsX2 & ADHD, ASD & Iqbal et al., 2013 \\
\hline & c. $9652 \mathrm{C}>\mathrm{T}$ & $\begin{array}{l}\text { p.13666LtsX2 } \\
\text { p.L3218F }\end{array}$ & $\begin{array}{l}\text { ID, hypotonia, spasticity } \\
\text { ID, brain atrophy, delayed myelination }\end{array}$ & Karaca et al., 2015 \\
\hline & c. $1990 \mathrm{G}>\mathrm{T}$ & p.G664* & ID, ASD, macrocephaly & Kloth et al., 2017 \\
\hline & c.11033del & p.P3678Lfs *45 & ID & Hu et al., 2019 \\
\hline & c. $4960 \mathrm{G}>\mathrm{T}, \mathrm{c} .4465 \mathrm{C}>\mathrm{T}$ & p.D1654Y, p.P1489S & Severe intractable seizures with DD & Zhu et al., 2020 \\
\hline \multirow{29}{*}{$\begin{array}{c}\text { SPTAN1 } \\
\text { (SPECTRIN, ALPHAII) } \\
\text { NM_0011304 } \\
(9 \mathrm{q} 34.11)\end{array}$} & $\begin{array}{l}\text { c.6619-6621del } \\
\text { c.6923-6928dup }\end{array}$ & $\begin{array}{c}\text { p.E2207del } \\
\text { p.R2308_M2309dup }\end{array}$ & WS, profound ID, spastic quadriplegia & Saitsu et al., 2010 \\
\hline & $\begin{array}{l}\text { c. } 1697 \mathrm{G}>\mathrm{C} \\
\text { c. } 6605-6607 \mathrm{del}\end{array}$ & $\begin{array}{l}\text { p.R566P } \\
\text { p.Q2202del }\end{array}$ & Mild ID, IS & Hamdan et al., 2012 \\
\hline & c.6908-6916 dup & p.D2303_L2305dup & $\begin{array}{l}\text { WS, severely impaired psychomotor } \\
\text { development }\end{array}$ & Nonoda et al., 2013 \\
\hline & c.6910_6918 dup & p.Q2304_G2306dup & WS & Ream and Mikati 2014 \\
\hline & c.5326C > T & p.R1776W & $\begin{array}{l}\text { Infantile EE with IS and focal epilepsy, } \\
\text { mild ID, ASD }\end{array}$ & Syrbe et al., 2017 \\
\hline & c. $6184 \mathrm{C}>\mathrm{T}$ & p.R2062W & $\begin{array}{c}\text { Infantile EE with tonic spasms and FDS, } \\
\text { profound DD, severe hypotonia, } \\
\text { microcephaly }\end{array}$ & \\
\hline & c.6619_6621del & p.E2207del & $\begin{array}{l}\text { WS, profound DD, minimal interaction, } \\
\text { hypotonia, hypokinesia; microcephaly }\end{array}$ & \\
\hline & c.6619_6621del & p.E2207del & $\begin{array}{l}\text { WS, profound DD, hypotonia, } \\
\text { microcephaly }\end{array}$ & \\
\hline & c.6622_6624del & p.N2208del & $\begin{array}{l}\text { WS, profound DD, severe hypotonia, } \\
\text { thermic dysregulation; microcephaly }\end{array}$ & \\
\hline & c. $6811 \mathrm{G}>\mathrm{A}$ & p.E2271K & $\begin{array}{l}\text { WS, profound DD, hypotonia, multifocal } \\
\text { myoclonus, dyskinetic movement } \\
\text { disorder, microcephaly }\end{array}$ & \\
\hline & c.6850_6852del & p.D2284del & $\begin{array}{l}\text { Infantile EE with IS evolving to } \\
\text { myoclonic seizures, severe DD, } \\
\text { hypotonia, ataxic movement disorder }\end{array}$ & \\
\hline & c.6908_6916dup & p.D2303_2305dup & $\begin{array}{l}\text { WS, profound DD, hypotonia, ataxia, } \\
\text { dyskinetic movement disorder, }\end{array}$ & \\
\hline & c.6908_6916dup & p.D2303_2305dup & $\begin{array}{l}\text { WS (PEHO syndrome), profound DD, } \\
\text { hypotonia, microcephaly }\end{array}$ & \\
\hline & c.6908_6916dup & p.D2303_2305dup & $\begin{array}{l}\text { WS, profound DD, hypotonia, } \\
\text { microcephaly }\end{array}$ & \\
\hline & c.6907_6915dup & p.D2303_2305dup & $\begin{array}{l}\text { WS, profound DD, hypotonia, ataxia, } \\
\text { dyskinetic movement disorder, } \\
\text { microcephaly }\end{array}$ & \\
\hline & c.6907_6915dup & p.D2303_2305dup & $\begin{array}{l}\text { WS, profound DD, intermittent } \\
\text { opisthotonus, hypotonia, microcephaly }\end{array}$ & \\
\hline & c.6910_6918del & p.Q2304_G2306del & WS, mild ID, DD, delayed walking & \\
\hline & c.6923_6928dup & p.R2308_M2309dup & WS, profound DD, microcephaly & \\
\hline & c. $533 \mathrm{G}>\mathrm{A}$ & p.G178D & Focal epilepsy & \\
\hline & c. $917 \mathrm{C}>\mathrm{T}$ & p.A306V & $\begin{array}{l}\text { Epilepsy with myoclonic and atonic } \\
\text { seizures, moderate ID }\end{array}$ & \\
\hline & c. $3716 \mathrm{~A}>\mathrm{G}$ & p.H1239R & $\begin{array}{l}\text { No epilepsy, mild DD, ID, ASD; mild } \\
\text { dysmorphic signs }\end{array}$ & \\
\hline & $\begin{array}{l}\text { c. } 4828 C>\text { T } \\
\text { c. } 6908 \_6916 \mathrm{del}\end{array}$ & $\begin{array}{c}\text { p.R1610W } \\
\text { p.D2303_L2305del }\end{array}$ & $\begin{array}{l}\text { Myoclonic epilepsy, mild-moderate DD, } \\
\text { ID, ASD, hypotonia, mild spastic gait; } \\
\text { hyperreflexia in lower limbs }\end{array}$ & \\
\hline & $\operatorname{arr}[$ hg19] 9q34.11 & p.A927_L1002del & FDS, moderate ID, ADHD & \\
\hline & $(131,349,701-131,351,531)$ & & Focal seizures, mild DD, ID, mild diffuse & \\
\hline & exon $20-21$ deletion & & $\begin{array}{c}\text { hypotonia, slowly progressive and severe } \\
\text { cerebellar ataxia }\end{array}$ & \\
\hline & heterozygous c.415C4T & p.R139* & Hereditary motor neuropathy & Beijer et al., 2019 \\
\hline & heterozygous c.4615C4T & p.Q1539* & & \\
\hline & heterozygous c.6385C4T & p.Q2149* & & \\
\hline & heterozygous c.6781C4T & p.R2261* & & Dong et al., 2021 \\
\hline
\end{tabular}


Table 1. Cont.

\begin{tabular}{|c|c|c|c|c|}
\hline $\begin{array}{c}\text { Gene Name } \\
\text { Accession \# } \\
\text { (Chromosome \#) }\end{array}$ & Gene Mutation Locus & Mutated Protein & Symptoms & References \\
\hline \multirow{9}{*}{$\begin{array}{c}\text { SPTBN4 } \\
\text { (SPECTRIN, BETAIV) } \\
\text { NM_020971.2 } \\
(19 \mathrm{q} 13.2)\end{array}$} & homozygous c.1597C > T & p.Q533* & $\begin{array}{l}\text { Congenital myopathy, neuropathy, } \\
\text { and central deafness }\end{array}$ & Knierim et al., 2017 \\
\hline & homozygous c.3394del & p.H1132Tfs *39 & $\begin{array}{l}\text { Global DD, hypotonia, dysphasia, } \\
\text { recurrent respiratory infections, blue } \\
\text { sclerae, hyporeflexia }\end{array}$ & Anazi et al., 2017 \\
\hline & & & \multirow{5}{*}{$\begin{array}{l}\text { Profound ID, congenital hypotonia, } \\
\text { and motor axonal neuropathy }\end{array}$} & \multirow{5}{*}{ Wang et al., 2019} \\
\hline & homozygous c.3820G > T & p.E1274* & & \\
\hline & homozygous c. $2709 \mathrm{G}>\mathrm{A}$ & p.W903* & & \\
\hline & $\begin{array}{l}\text { c. } 1511 \mathrm{G}>\mathrm{A} ; \mathrm{c} .7303 \mathrm{C}>\mathrm{T} \\
\text { homozygous c.7453del }\end{array}$ & $\begin{array}{l}\text { p.R504Q; p.R2435C } \\
\text { p.A2485Lfs *31 }\end{array}$ & & \\
\hline & c.1813C > T; c.3829del & p.Q605*, p.Q1277Rfs *4 & & \\
\hline & homozygous c. $1665+2 \mathrm{~T}>\mathrm{C}$ & Intron & $\begin{array}{l}\text { Speech delay, ID, ataxia, seizures, } \\
\text { cerebral atrophy }\end{array}$ & Monies et al., 2019 \\
\hline & homozygous c.3949-1G > A & Intron & Axonal neuropathy without ID & Hausler et al., 2020 \\
\hline
\end{tabular}

Abbreviations: number (\#); termination codon $(*)$; frame shift (fs); duplication (dup); deletion (del); autism spectrum disorder (ASD); attention deficit hyperactivity disorder (ADHD); intellectual disability (ID); West syndrome (WS); developmental delay (DD); epileptic encephalopathy (EE); infantile spasms (IS); focal dyscognitive seizures (FDS); progressive encephalopathy (PEHO).

In patients with bipolar disorder (BD), several studies have shown that $A N K-3$ has strong predisposition to $\mathrm{BD}$ in a genome-wide association study [84-86]. Exon variation has also been intensively investigated in patients with BD. Interestingly, exon variation at a $\mathrm{BD}$-associated SNP correlates with a significant difference in the cerebellar expression of a brain-specific ANK-3 transcript and contributes to disease pathology [87,88]. ANK-3 is also associated with schizophrenia [89-91].

Recently, whole-exome sequencing allowed the identification of a pathogenic mutation in the ANK-3 gene of patients with ASD (Table 1) [92]. In addition, another mutation has been identified within a family of patients with ASD [93]. Iqbal et al. reported multiple types of $A N K-3$ mutations in patients with NDDs [94]: one patient had borderline intelligence, ADHD, ASD, and cognitive problems caused by the balanced chromosomal translocation of $A N K-3$, and in a Pakistani family, moderate ID, and ADHD-like phenotype and behavioral problems were associated with a homozygous single base pair truncating frameshift mutation in ANK-3 [94]. Subsequently, several ANK-3 mutations were found in patients with ID [95-98]. More recently, two patients with NDDs and ANK-3 mutations were identified; each exhibited mild-to-borderline ID, ASD-like features, and speech delays. One patient also exhibited developmental delays, seizures, cognitive impairment, ataxia, retinal dystrophy, and small stature [99].

The first pathogenic variant was found in SPTAN1 in patients with West syndrome, a constellation of symptoms primarily characterized by epileptic/infantile spasms, abnormal brain electroencephalography (EEG) patterns called hypsarrhythmia, and ID (Table 1); two patients possessed a heterozygous in-frame $3 \mathrm{bp}$ deletion or $6 \mathrm{bp}$ duplication in $S P$ TAN1 [100]. The patients exhibited intractable seizures at three months of age and showed ID, poor visual attention, a lack of speech development, and spastic quadriplegia; in addition, brain magnetic resonance imaging (MRI) showed diffuse hypomyelination and extensive brain atrophy. Subsequently, several studies have also identified a mutation in SPTAN1 in patients with a wide spectrum of neurodevelopmental phenotypes ranging from mild to severe (Table 1) [101-104].

In addition, four heterozygous mutations in SPTAN1 were recently identified in four different families with juvenile-onset hereditary motor neuropathy, a particularly rare subgroup of inherited peripheral neuropathies $[105,106]$. These patients typically exhibited a length-dependent axonal degeneration of lower motor neurons without the apparent involvement of sensory neurons [105,106].

Recently, the first pathogenic variant of SPTBN4 was reported [107]. Other studies have also shown mutations in SPTBN4 [108-112]. These congenital diseases are defined as SPTBN4 disorder or, alternatively, neurodevelopmental disorder with hypotonia, neuropathy, and deafness (NEDHND) [113]. 
These results indicate that mutations in these AIS regulatory proteins are important to the development of the CNS.

\section{Abnormal AIS Characteristics in Neurodevelopmental Disorders}

Studies on human mutations have shown that molecules that regulate the AIS are highly related to brain development. Finally, we discuss the changes in the properties of the AIS in animal models and patients with NDDs, as well as the potential use of homeostatic regulation for the treatment of NDDs.

The first report by Kaphzan et al. showed a significant increase in the AIS length of hippocampal pyramidal neurons in vivo in an Angelman syndrome (AS) mouse model [114]. AS is an NDD caused by a loss of function of the maternally inherited UBE3A gene and is associated with symptoms of ID, epilepsy, cerebellar ataxia, sleep disorders; AS also shows high comorbidity with ASD. Changes were also found in the amplitude of the resting membrane potential, threshold potential, and action potential [114]. Interestingly, CA1 and CA3 pyramidal neurons have a significantly longer AIS, whereas cortical neurons in the somatosensory area do not show alterations [114]. This is the first in vivo evidence of changes in the AIS in an animal model of NDDs [114].

As mentioned earlier, a mutation in the ANK-3 gene, which encodes the $480 \mathrm{kDa}$ ankyrin-G isomer, induces NDDs in humans [99]. In addition, disruption of exon 37 induces a specific giant ankyrin-G disruption, and exon 37 knockout mice showed reduced cortical gamma oscillations, which are associated with higher cognitive processes [99]. Further behavioral investigations of exon 37 knockout mouse or new animal models of AIS protein with human disease mutation, may strongly support the use of the mouse as an ideal model animal for NDDs.

More recently, in a mouse model of the fragile X syndrome, Booker et al. showed that the length of the AIS in CA1 neurons in the Fmr1 ${ }^{-/ y}$ mouse hippocampus elongated with increasing cellular excitability. This change in length was not due to a decrease in AIS plasticity but instead to a reduced input from the entorhinal cortex. These results indicate that the length of the AIS and cellular intrinsic hyperexcitability may reflect a decrease in the synaptic input to CA1 neurons in a non-cell-autonomous fashion by homeostatic mechanisms [115].

In humans, Hong et al. showed that the $\alpha 2-\mathrm{GABA}_{\mathrm{A}} \mathrm{R}$ protein is reduced in the AIS of pyramidal cells in the prefrontal cortex in patients with ASD [116]. They first showed a significant decrease in the number of ChCs in the prefrontal cortex of patients with ASD [117], and that the reduction in $\alpha 2-G_{A B A} R$ in the pyramidal cell AIS was localized to layer III in ASD patients, presumably due to ChC reduction [116]. These results support the idea that $\mathrm{ChCs}$ regulate the cortical excitability of pyramidal neurons in the AIS domain.

Another study found that, in mouse models of ASD, mice with mutations in the transcription factor PAX6 exhibited changes of the AIS that were significantly further from the cell body and exhibited a longer AnkG staining of prethalamic neurons [118].

Taken together, these results suggest that the AIS is an indicator of structural changes as well as abnormal and homeostatic plastic changes in response to the dysfunction of neural circuits.

\section{Conclusions}

As discussed above, a growing body of evidence suggests the importance of the pathophysiological role of abnormal AISs in NDDs. This then prompts the question: can we take advantage of these concepts to develop future treatments or diagnostic tools based on AIS changes? One of the most promising uses of the AIS is as a biomarker for aberrant neural circuits in neurological and psychiatric disorders. In a variety of neurological and psychiatric disease models, an abnormal AIS length has been widely observed [68-74,114,115]. To determine cell-specific neural circuit abnormalities, researchers can use viral or classical retrograde or anterograde tracing methods in disease models. Then, chemogenetic or 
optogenetic techniques can be applied to modulate circuit activity and prove the aberrant circuits responsible for disease.

On the other hand, we may also ask: are there any potential therapies for NDDs? According to an excellent review from 2021, we now have several future opportunities to manage NDDs therapeutically at genome, protein, neural circuit, and individual levels using recent technical advances such as CRISPR-Cas9, optogenetics, chemogenetics, the transplantation of differentiated neurons, and various brain stimulation methods [119].

In particular, according to the results of a human study on ChCs in ASD [116], ChCs may be decreased in the ASD brain; therefore, it may be useful to transplant human ChCs that are differentiated from pluripotent cells into patients with ASD [119].

Recent advances in ultrasensitive optogenetics may allow the use of implant-free deep brain optogenetics that could be used for human neural circuit-specific therapy $[120,121]$. If abnormal neural circuits were determined in disease models, human neural circuits could be modulated by the viral vector with optogenetic methods, even deep in the brain.

Author Contributions: Conceptualization, M.F.; writing-original draft preparation, M.F.; writingreview and editing, Y.O. and H.M.; visualization, Y.O. and H.M. All authors have read and agreed to the published version of the manuscript.

Funding: This research was funded by the Japan Society for the promotion of Science, JSPS, 18K06474 for M.F., 19K16267 for Y.O. This research was funded by the Osaka medical research foundation for intractable diseases and the Ichiro Kanehara Foundation for the Promotion of Medical Sciences and Medical Care for Y.O.

Institutional Review Board Statement: Not applicable.

Informed Consent Statement: Not applicable.

Data Availability Statement: No new data were created or analyzed in this study. Data sharing is not applicable to this article.

Acknowledgments: We gratefully acknowledge the work of the present members of our laboratory and the Kuwako laboratory.

Conflicts of Interest: The authors declare no conflict of interest.

\section{References}

1. Huang, C.Y.; Rasband, M.N. Axon Initial Segments: Structure, Function, and Disease. Ann. N. Y. Acad. Sci. 2018, $1420,46-61$. [CrossRef] [PubMed]

2. Leterrier, C. The Axon Initial Segment: An Updated Viewpoint. J. Neurosci. 2018, 38, 2135-2145. [CrossRef] [PubMed]

3. Bennett, V.; Lorenzo, D.N. Spectrin- and Ankyrin-Based Membrane Domains and the Evolution of Vertebrates. Curr. Top. Membr. 2013, 72, 1-37. [CrossRef] [PubMed]

4. Nelson, A.D.; Jenkins, P.M. Axonal Membranes and Their Domains: Assembly and Function of the Axon Initial Segment and Node of Ranvier. Front. Cell. Neurosci. 2017, 11, 136. [CrossRef]

5. Palay, S.L.; Sotelo, C.; Peters, A.; Orkand, P.M. The Axon Hillock and the Initial Segment. J. Cell Biol. 1968, 38, 193-201. [CrossRef] [PubMed]

6. Peters, A.; Proskauer, C.C.; Kaiserman-Abramof, I.R. The Small Pyramidal Neuron of the Rat Cerebral Cortex. The Axon Hillock and Initial Segment. J. Cell Biol. 1968, 39, 604-619. [CrossRef]

7. Lorincz, A.; Nusser, Z. Cell-Type-Dependent Molecular Composition of the Axon Initial Segment. J. Neurosci. 2008, 28, 1432914340. [CrossRef]

8. Kuba, H.; Ishii, T.M.; Ohmori, H. Axonal Site of Spike Initiation Enhances Auditory Coincidence Detection. Nature 2006, 444, 1069-1072. [CrossRef]

9. Bender, K.J.; Trussell, L.O. The Physiology of the Axon Initial Segment. Annu. Rev. Neurosci. 2012, 35, 249-265. [CrossRef]

10. Kole, M.H.; Stuart, G.J. Signal Processing in the Axon Initial Segment. Neuron 2012, 73, 235-247. [CrossRef] [PubMed]

11. Yamada, R.; Kuba, H. Structural and Functional Plasticity at the Axon Initial Segment. Front. Cell. Neurosci. 2016, 10, 250. [CrossRef]

12. Kordeli, E.; Lambert, S.; Bennett, V.; Ankyrin, G. AnkyrinG. A New Ankyrin Gene with Neural-Specific Isoforms Localized at the Axonal Initial Segment and Node of Ranvier. J. Biol. Chem. 1995, 270, 2352-2359. [CrossRef]

13. Jenkins, P.M.; Kim, N.; Jones, S.L.; Tseng, W.C.; Svitkina, T.M.; Yin, H.H.; Bennett, V. Giant Ankyrin-G: A Critical Innovation in Vertebrate Evolution of Fast and Integrated Neuronal Signaling. Proc. Natl. Acad. Sci. USA 2015, 112, 957-964. [CrossRef] 
14. Boiko, T.; Vakulenko, M.; Ewers, H.; Yap, C.C.; Norden, C.; Winckler, B. Ankyrin-Dependent and -Independent Mechanisms Orchestrate Axonal Compartmentalization of L1 Family Members Neurofascin and L1/Neuron-Glia Cell Adhesion Molecule. J. Neurosci. 2007, 27, 590-603. [CrossRef]

15. Galiano, M.R.; Jha, S.; Ho, T.S.; Zhang, C.; Ogawa, Y.; Chang, K.J.; Stankewich, M.C.; Mohler, P.J.; Rasband, M.N. A Distal Axonal Cytoskeleton Forms an Intra-Axonal Boundary That Controls Axon Initial Segment Assembly. Cell 2012, 149, 1125-1139. [CrossRef]

16. Zhou, D.X.; Lambert, S.; Malen, P.L.; Carpenter, S.; Boland, L.M.; Bennett, V. Ankyring Is Required for Clustering of Voltage-Gated Na Channels at Axon Initial Segments and for Normal Action Potential Firing. Mol. Biol. Cell 1998, 143, 1295-1304. [CrossRef] [PubMed]

17. Jenkins, S.M.; Bennett, V. Ankyrin-G Coordinates Assembly of the Spectrin-Based Membrane Skeleton, Voltage-Gated Sodium Channels, and L1 CAMs at Purkinje Neuron Initial Segments. J. Cell Biol. 2001, 155, 739-746. [CrossRef] [PubMed]

18. Hedstrom, K.L.; Xu, X.; Ogawa, Y.; Frischknecht, R.; Seidenbecher, C.I.; Shrager, P.; Rasband, M.N. Neurofascin Assembles a Specialized Extracellular Matrix at the Axon Initial Segment. J. Cell Biol. 2007, 178, 875-886. [CrossRef] [PubMed]

19. Legendre, K.; Safieddine, S.; Küssel-Andermann, P.; Petit, C.; El-Amraoui, A. alphaII-betaV Spectrin Bridges the Plasma Membrane and Cortical Lattice in the Lateral Wall of the Auditory Outer Hair Cells. J. Cell Sci. 2008, 121, 3347-3356. [CrossRef]

20. Berghs, S.; Aggujaro, D.; Dirkx, R.; Maksimova, E.; Stabach, P.; Hermel, J.M.; Zhang, J.P.; Philbrick, W.; Slepnev, V.; Ort, T.; et al. Beta IV Spectrin, a New Spectrin Localized at Axon Initial Segments and Nodes of Ranvier in the Central and Peripheral Nervous System. J. Cell Biol. 2000, 151, 985-1002. [CrossRef]

21. Huang, C.Y.; Zhang, C.; Zollinger, D.R.; Leterrier, C.; Rasband, M.N. An alphaII Spectrin-Based Cytoskeleton Protects LargeDiameter Myelinated Axons from Degeneration. J. Neurosci. 2017, 37, 11323-11334. [CrossRef]

22. Huang, C.Y.; Zhang, C.; Ho, T.S.; Oses-Prieto, J.; Burlingame, A.L.; Lalonde, J.; Noebels, J.L.; Leterrier, C.; Rasband, M.N. alphaII Spectrin Forms a Periodic Cytoskeleton at the Axon Initial Segment and Is Required for Nervous System Function. J. Neurosci. 2017, 37, 11311-11322. [CrossRef]

23. Stankewich, M.C.; Cianci, C.D.; Stabach, P.R.; Ji, L.; Nath, A.; Morrow, J.S. Cell Organization, Growth, and Neural and Cardiac Development Require alphaII-spectrin. J. Cell Sci. 2011, 124, 3956-3966. [CrossRef] [PubMed]

24. Wang, Y.; Ji, T.; Nelson, A.D.; Glanowska, K.; Murphy, G.G.; Jenkins, P.M.; Parent, J.M. Critical Roles of alphaII Spectrin in Brain Development and Epileptic Encephalopathy. J. Clin. Investig. 2018, 128, 760-773. [CrossRef] [PubMed]

25. Liu, C.H.; Seo, R.; Ho, T.S.; Stankewich, M.; Mohler, P.J.; Hund, T.J.; Noebels, J.L.; Rasband, M.N.; Rasband, M.N. Beta Spectrin-Dependent and Domain Specific Mechanisms for $\mathrm{Na}^{+}$Channel Clustering. eLife 2020, 9, e56629. [CrossRef] [PubMed]

26. Yoshimura, T.; Rasband, M.N. Axon Initial Segments: Diverse and Dynamic Neuronal Compartments. Curr. Opin. Neurobiol. 2014, 27, 96-102. [CrossRef] [PubMed]

27. Kuijpers, M.; van de Willige, D.; Freal, A.; Chazeau, A.; Franker, M.A.; Hofenk, J.; Rodrigues, R.J.; Kapitein, L.C.; Akhmanova, A.; Jaarsma, D.; et al. Dynein Regulator NDEL1 Controls Polarized Cargo Transport at the Axon Initial Segment. Neuron 2016, 89, 461-471. [CrossRef]

28. Davis, J.Q.; Lambert, S.; Bennett, V. Molecular Composition of the Node of Ranvier: Identification of Ankyrin-Binding Cell Adhesion Molecules Neurofascin (Mucin+/third FNIII Domain-) and NrCAM at Nodal Axon Segments. J. Cell Biol. 1996, 135, 1355-1367. [CrossRef]

29. Zonta, B.; Desmazieres, A.; Rinaldi, A.; Tait, S.; Sherman, D.L.; Nolan, M.F.; Brophy, P.J. A Critical Role for Neurofascin in Regulating Action Potential Initiation Through Maintenance of the Axon Initial Segment. Neuron 2011, 69, 945-956. [CrossRef]

30. Alpizar, S.A.; Baker, A.L.; Gulledge, A.T.; Hoppa, M.B. Loss of Neurofascin-186 Disrupts Alignment of AnkyrinG Relative to Its Binding Partners in the Axon Initial Segment. Front. Cell. Neurosci. 2019, 13, 1. [CrossRef]

31. Leterrier, C.; Clerc, N.; Rueda-Boroni, F.; Montersino, A.; Dargent, B.; Castets, F.; Ankyrin, G. Ankyrin G Membrane Partners Drive the Establishment and Maintenance of the Axon Initial Segment. Front. Cell. Neurosci. 2017, 11, 6. [CrossRef] [PubMed]

32. Leterrier, C.; Vacher, H.; Fache, M.P.; d'Ortoli, S.A.; Castets, F.; Autillo-Touati, A.; Dargent, B. End-Binding Proteins EB3 and EB1 Link Microtubules to Ankyrin G in the Axon Initial Segment. Proc. Natl. Acad. Sci. USA 2011, 108, 8826-8831. [CrossRef]

33. Van Beuningen, S.F.B.; Will, L.; Harterink, M.; Chazeau, A.; van Battum, E.Y.; Frias, C.P.; Franker, M.A.M.; Katrukha, E.A.; Stucchi, R.; Vocking, K.; et al. TRIM46 Controls Neuronal Polarity and Axon Specification by Driving the Formation of Parallel Microtubule Arrays. Neuron 2015, 88, 1208-1226. [CrossRef]

34. Satake, T.; Yamashita, K.; Hayashi, K.; Miyatake, S.; Tamura-Nakano, M.; Doi, H.; Furuta, Y.; Shioi, G.; Miura, E.; Takeo, Y.H.; et al MTCL1 Plays an Essential Role in Maintaining Purkinje Neuron Axon Initial Segment. EMBO J. 2017, 36, 1227-1242. [CrossRef]

35. Ogawa, Y.; Oses-Prieto, J.; Kim, M.Y.; Horresh, I.; Peles, E.; Burlingame, A.L.; Trimmer, J.S.; Meijer, D.; Rasband, M.N.A. ADAM22, a Kv1 Channel-Interacting Protein, Recruits Membrane-Associated Guanylate Kinases to Juxtaparanodes of Myelinated Axons. J. Neurosci. 2010, 30, 1038-1048. [CrossRef]

36. Bréchet, A.; Fache, M.P.; Brachet, A.; Ferracci, G.; Baude, A.; Irondelle, M.; Pereira, S.; Leterrier, C.; Dargent, B. Protein Kinase CK2 Contributes to the Organization of Sodium Channels in Axonal Membranes by Regulating Their Interactions with Ankyrin G. J. Cell Biol. 2008, 183, 1101-1114. [CrossRef] [PubMed]

37. Berger, S.L.; Leo-Macias, A.; Yuen, S.; Khatri, L.; Pfennig, S.; Zhang, Y.; Agullo-Pascual, E.; Caillol, G.; Zhu, M.S.; Rothenberg, E.; et al. Localized Myosin II Activity Regulates Assembly and Plasticity of the Axon Initial Segment. Neuron 2018, 97, 555-570.e6. [CrossRef] 
38. Abouelezz, A.; Stefen, H.; Segerstråle, M.; Micinski, D.; Minkeviciene, R.; Lahti, L.; Hardeman, E.C.; Gunning, P.W.; Hoogenraad, C.C.; Taira, T.; et al. Tropomyosin Tpm3.1 Is Required to Maintain the Structure and Function of the Axon Initial Segment. iScience 2020, 23, 101053. [CrossRef] [PubMed]

39. Hamdan, H.; Lim, B.C.; Torii, T.; Joshi, A.; Konning, M.; Smith, C.; Palmer, D.J.; Ng, P.; Leterrier, C.; Oses-Prieto, J.A.; et al. Mapping Axon Initial Segment Structure and Function by Multiplexed Proximity Biotinylation. Nat. Commun. 2020, 11, 100. [CrossRef] [PubMed]

40. Xu, K.; Zhong, G.; Zhuang, X. Actin, Spectrin, and Associated Proteins Form a Periodic Cytoskeletal Structure in Axons. Science 2013, 339, 452-456. [CrossRef] [PubMed]

41. Zhong, G.; He, J.; Zhou, R.; Lorenzo, D.; Babcock, H.P.; Bennett, V.; Zhuang, X. Developmental Mechanism of the Periodic Membrane Skeleton in Axons. eLife 2014, 3, e04581. [CrossRef]

42. Leterrier, C.; Potier, J.; Caillol, G.; Debarnot, C.; Rueda Boroni, F.; Dargent, B. Nanoscale Architecture of the Axon Initial Segment Reveals an Organized and Robust Scaffold. Cell Rep. 2015, 13, 2781-2793. [CrossRef]

43. Jones, S.L.; Korobova, F.; Svitkina, T. Axon Initial Segment Cytoskeleton Comprises a Multiprotein Submembranous Coat Containing Sparse Actin Filaments. J. Cell Biol. 2014, 205, 67-81. [CrossRef]

44. Vassilopoulos, S.; Gibaud, S.; Jimenez, A.; Caillol, G.; Leterrier, C. Ultrastructure of the Axonal Periodic Scaffold Reveals a Braid-Like Organization of Actin Rings. Nat. Commun. 2019, 10, 5803. [CrossRef]

45. Leterrier, C. Putting the Axonal Periodic Scaffold in Order. Curr. Opin. Neurobiol. 2021, 69, 33-40. [CrossRef]

46. Boiko, T.; Van Wart, A.; Caldwell, J.H.; Levinson, S.R.; Trimmer, J.S.; Matthews, G. Functional Specialization of the Axon Initial Segment by Isoform-Specific Sodium Channel Targeting. J. Neurosci. 2003, 23, 2306-2313. [CrossRef]

47. Duflocq, A.; Le Bras, B.; Bullier, E.; Couraud, F.; Davenne, M. Nav1.1 Is Predominantly Expressed in Nodes of Ranvier and Axon Initial Segments. Mol. Cell. Neurosci. 2008, 39, 180-192. [CrossRef]

48. Kole, M.H.; Ilschner, S.U.; Kampa, B.M.; Williams, S.R.; Ruben, P.C.; Stuart, G.J. Action Potential Generation Requires a High Sodium Channel Density in the Axon Initial Segment. Nat. Neurosci. 2008, 11, 178-186. [CrossRef]

49. Schmidt-Hieber, C.; Bischofberger, J. Fast Sodium Channel Gating Supports Localized and Efficient Axonal Action Potential Initiation. J. Neurosci. 2010, 30, 10233-10242. [CrossRef]

50. Nathanson, A.J.; Davies, P.A.; Moss, S.J. Inhibitory Synapse Formation at the Axon Initial Segment. Front. Mol. Neurosci. 2019, 12, 266. [CrossRef]

51. DeFelipe, J.; Hendry, S.H.; Jones, E.G.; Schmechel, D. Variability in the Terminations of GABAergic Chandelier Cell Axons on Initial Segments of Pyramidal Cell Axons in the Monkey Sensory-Motor Cortex. J. Comp. Neurol. 1985, 231, 364-384. [CrossRef] [PubMed]

52. Somogyi, P. A Specific 'Axo-Axonal' Interneuron in the Visual Cortex of the Rat. Brain Res. 1977, 136, 345-350. [CrossRef]

53. Hines, R.M.; Maric, H.M.; Hines, D.J.; Modgil, A.; Panzanelli, P.; Nakamura, Y.; Nathanson, A.J.; Cross, A.; Deeb, T.; Brandon, N.J.; et al. Developmental Seizures and Mortality Result from Reducing GABAA Receptor alpha2-Subunit Interaction with Collybistin. Nat. Commun. 2018, 9, 3130. [CrossRef]

54. Inda, M.C.; Defelipe, J.; Muñoz, A. The Distribution of Chandelier Cell Axon Terminals That Express the GABA Plasma Membrane Transporter GAT-1 in the Human Neocortex. Cereb. Cortex 2007, 17, 2060-2071. [CrossRef] [PubMed]

55. Tai, Y.; Gallo, N.B.; Wang, M.; Yu, J.R.; Van Aelst, L. Axo-Axonic Innervation of Neocortical Pyramidal Neurons by GABAergic Chandelier Cells Requires AnkyrinG-Associated L1CAM. Neuron 2019, 102, 358-372.e9. [CrossRef]

56. Pan-Vazquez, A.; Wefelmeyer, W.; Gonzalez Sabater, V.; Neves, G.; Burrone, J. Activity-Dependent Plasticity of Axo-Axonic Synapses at the Axon Initial Segment. Neuron 2020, 106, 265-276.e6. [CrossRef] [PubMed]

57. Baalman, K.; Marin, M.A.; Ho, T.S.; Godoy, M.; Cherian, L.; Robertson, C.; Rasband, M.N. Axon Initial Segment-Associated Microglia. J. Neurosci. 2015, 35, 2283-2292. [CrossRef]

58. Tamada, H.; Kiryu-Seo, S.; Sawada, S.; Kiyama, H. Axonal Injury Alters the Extracellular Glial Environment of the Axon Initial Segment (AIS) and Allows Substantial Mitochondrial Influx into AIS. J. Comp. Neurol. 2021, 1-12. [CrossRef]

59. Molofsky, A.V.; Kelley, K.W.; Tsai, H.H.; Redmond, S.A.; Chang, S.M.; Madireddy, L.; Chan, J.R.; Baranzini, S.E.; Ullian, E.M.; Rowitch, D.H. Astrocyte-Encoded Positional Cues Maintain Sensorimotor Circuit Integrity. Nature 2014, 509, 189-194. [CrossRef]

60. Hamada, M.S.; Kole, M.H. Myelin Loss and Axonal Ion Channel Adaptations Associated with Gray Matter Neuronal Hyperexcitability. J. Neurosci. 2015, 35, 7272-7286. [CrossRef]

61. Moore, S.; Meschkat, M.; Ruhwedel, T.; Trevisiol, A.; Tzvetanova, I.D.; Battefeld, A.; Kusch, K.; Kole, M.H.P.; Strenzke, N.; Möbius, W.; et al. A Role of Oligodendrocytes in Information Processing. Nat. Commun. 2020, 11, 5497. [CrossRef] [PubMed]

62. Jamann, N.; Jordan, M.; Engelhardt, M. Activity-Dependent Axonal Plasticity in Sensory Systems. Neuroscience 2018, 368, 268-282. [CrossRef]

63. Evans, M.D.; Dumitrescu, A.S.; Kruijssen, D.L.H.; Taylor, S.E.; Grubb, M.S. Rapid Modulation of Axon Initial Segment Length Influences Repetitive Spike Firing. Cell Rep. 2015, 13, 1233-1245. [CrossRef] [PubMed]

64. Grubb, M.S.; Burrone, J. Activity-Dependent Relocation of the Axon Initial Segment Fine-Tunes Neuronal Excitability. Nature 2010, 465, 1070-1074. [CrossRef] [PubMed]

65. Kuba, H.; Oichi, Y.; Ohmori, H. Presynaptic Activity Regulates Na ${ }^{+}$Channel Distribution at the Axon Initial Segment. Nature 2010, 465, 1075-1078. [CrossRef] 
66. Akter, N.; Fukaya, R.; Adachi, R.; Kawabe, H.; Kuba, H. Structural and Functional Refinement of the Axon Initial Segment iNavian Cochlear Nucleus During Development. J. Neurosci. 2020, 40, 6709-6721. [CrossRef]

67. Yermakov, L.M.; Drouet, D.E.; Griggs, R.B.; Elased, K.M.; Susuki, K. Type 2 Diabetes Leads to Axon Initial Segment Shortening in $\mathrm{Db} / \mathrm{Db}$ Mice. Front. Cell. Neurosci. 2018, 12, 146. [CrossRef] [PubMed]

68. Harty, R.C.; Kim, T.H.; Thomas, E.A.; Cardamone, L.; Jones, N.C.; Petrou, S.; Wimmer, V.C. Axon Initial Segment Structural Plasticity in Animal Models of Genetic and Acquired Epilepsy. Epilepsy Res. 2013, 105, 272-279. [CrossRef] [PubMed]

69. Hinman, J.D.; Rasband, M.N.; Carmichael, S.T. Remodeling of the Axon Initial Segment After Focal Cortical and White Matter Stroke. Stroke 2013, 44, 182-189. [CrossRef]

70. Benusa, S.D.; George, N.M.; Sword, B.A.; DeVries, G.H.; Dupree, J.L. Acute Neuroinflammation Induces AIS Structural Plasticity in a NOX2-Dependent Manner. J. Neuroinflamm. 2017, 14, 116. [CrossRef]

71. Vascak, M.; Sun, J.; Baer, M.; Jacobs, K.M.; Povlishock, J.T. Mild Traumatic Brain Injury Evokes Pyramidal Neuron Axon Initial Segment Plasticity and Diffuse Presynaptic Inhibitory Terminal Loss. Front. Cell. Neurosci. 2017, 11, 157. [CrossRef]

72. Sun, X.; Wu, Y.; Gu, M.; Liu, Z.; Ma, Y.; Li, J.; Zhang, Y. Selective Filtering Defect at the Axon Initial Segment in Alzheimer's Disease Mouse Models. Proc. Natl. Acad. Sci. USA 2014, 111, 14271-14276. [CrossRef] [PubMed]

73. Jørgensen, H.S.; Jensen, D.B.; Dimintiyanova, K.P.; Bonnevie, V.S.; Hedegaard, A.; Lehnhoff, J.; Moldovan, M.; Grondahl, L.; Meehan, C.F. Increased Axon Initial Segment Length Results in Increased Na+ Currents in Spinal Motoneurones at Symptom Onset in the G127X SOD1 Mouse Model of Amyotrophic Lateral Sclerosis. Neuroscience 2021, 468, 247-264. [CrossRef]

74. Sohn, P.D.; Huang, C.T.; Yan, R.; Fan, L.; Tracy, T.E.; Camargo, C.M.; Montgomery, K.M.; Arhar, T.; Mok, S.A.; Freilich, R.; et al. Pathogenic Tau Impairs Axon Initial Segment Plasticity and Excitability Homeostasis. Neuron 2019, 104, 458-470.e5. [CrossRef]

75. Gutzmann, A.; Ergül, N.; Grossmann, R.; Schultz, C.; Wahle, P.; Engelhardt, M. A Period of Structural Plasticity at the Axon Initial Segment in Developing Visual Cortex. Front. Neuroanat. 2014, 8, 11. [CrossRef] [PubMed]

76. Schlüter, A.; Del Turco, D.; Deller, T.; Gutzmann, A.; Schultz, C.; Engelhardt, M. Structural Plasticity of Synaptopodin in the Axon Initial Segment During Visual Cortex Development. Cereb. Cortex 2017, 27, 4662-4675. [CrossRef] [PubMed]

77. Kim, E.J.; Feng, C.; Santamaria, F.; Kim, J.H. Impact of Auditory Experience on the Structural Plasticity of the AIS in the Mouse Brainstem Throughout the Lifespan. Front. Cell. Neurosci. 2019, 13, 456. [CrossRef] [PubMed]

78. Jamann, N.; Dannehl, D.; Lehmann, N.; Wagener, R.; Thielemann, C.; Schultz, C.; Staiger, J.; Kole, M.H.P.; Engelhardt, M. Sensory Input Drives Rapid Homeostatic Scaling of the Axon Initial Segment in Mouse Barrel Cortex. Nat. Commun. 2021, 12, 23. [CrossRef]

79. Galliano, E.; Hahn, C.; Browne, L.P.; Villamayor, P.R.; Tufo, C.; Crespo, A.; Grubb, M.S. Brief Sensory Deprivation Triggers Cell Type-Specific Structural and Functional Plasticity in Olfactory Bulb Neurons. J. Neurosci. 2021, 41, 2135-2151. [CrossRef]

80. American Psychiatric Association. Diagnostic and Statistical Manual of Mental Disorders (DSM-5), 5th ed.; American Psychiatric Association: Arlington County, VA, USA, 2013.

81. Thapar, A.; Cooper, M.; Rutter, M. Neurodevelopmental Disorders. Lancet Psychiatry 2017, 4, 339-346. [CrossRef]

82. Spillane, J.; Kullmann, D.M.; Hanna, M.G. Genetic Neurological Channelopathies: Molecular Genetics and Clinical Phenotypes. J. Neurol. Neurosurg. Psychiatry 2016, 87, 37-48. [CrossRef]

83. Wimmer, V.C.; Reid, C.A.; So, E.Y.; Berkovic, S.F.; Petrou, S. Axon Initial Segment Dysfunction in Epilepsy. J. Physiol. 2010, 588, 1829-1840. [CrossRef]

84. Ferreira, M.A.; O’Donovan, M.C.; Meng, Y.A.; Jones, I.R.; Ruderfer, D.M.; Jones, L.; Fan, J.; Kirov, G.; Perlis, R.H.; Green, E.K.; et al. Wellcome Trust Case Control Consortium. Collaborative Genome-Wide Association Analysis Supports a Role for ANK3 and CACNA1C in Bipolar Disorder. Nat. Genet. 2008, 40, 1056-1058. [CrossRef] [PubMed]

85. Leussis, M.P.; Madison, J.M.; Petryshen, T.L. Ankyrin 3: Genetic Association with Bipolar Disorder and Relevance to Disease Pathophysiology. Biol. Mood Anxiety Disord. 2012, 2, 18. [CrossRef]

86. Zhang, C.; Xiao, X.; Li, T.; Li, M. Translational Genomics and Beyond in Bipolar Disorder. Mol. Psychiatry 2021, 26, 186-202. [CrossRef] [PubMed]

87. Rueckert, E.H.; Barker, D.; Ruderfer, D.; Bergen, S.E.; O’Dushlaine, C.; Luce, C.J.; Sheridan, S.D.; Theriault, K.M.; Chambert, K.; Moran, J.; et al. cis-Acting Regulation of Brain-Specific ANK3 Gene Expression by a Genetic Variant Associated with Bipolar Disorder. Mol. Psychiatry 2013, 18, 922-929. [CrossRef] [PubMed]

88. Lopez, A.Y.; Wang, X.; Xu, M.; Maheshwari, A.; Curry, D.; Lam, S.; Adesina, A.M.; Noebels, J.L.; Sun, Q.Q.; Cooper, E.C. Ankyrin-G Isoform Imbalance and Interneuronopathy Link Epilepsy and Bipolar Disorder. Mol. Psychiatry 2017, 22, 1464-1472. [CrossRef] [PubMed]

89. Schizophrenia Psychiatric Genome-Wide Association Study (GWAS) Consortium. Genome-Wide Association Study Identifies Five New Schizophrenia Loci. Nat. Genet. 2011, 43, 969-976. [CrossRef]

90. Roussos, P.; Katsel, P.; Davis, K.L.; Bitsios, P.; Giakoumaki, S.G.; Jogia, J.; Rozsnyai, K.; Collier, D.; Frangou, S.; Siever, L.J.; et al. Molecular and Genetic Evidence for Abnormalities in the Nodes of Ranvier in Schizophrenia. Arch. Gen. Psychiatry 2012, 69, 7-15. [CrossRef]

91. Athanasiu, L.; Mattingsdal, M.; Kähler, A.K.; Brown, A.; Gustafsson, O.; Agartz, I.; Giegling, I.; Muglia, P.; Cichon, S.; Rietschel, M.; et al. Gene Variants Associated with Schizophrenia in a Norwegian Genome-Wide Study Are Replicated in a Large European Cohort. J. Psychiatr. Res. 2010, 44, 748-753. [CrossRef] 
92. Bi, C.; Wu, J.; Jiang, T.; Liu, Q.; Cai, W.; Yu, P.; Cai, T.; Zhao, M.; Jiang, Y.H.; Sun, Z.S. Mutations of ANK3 Identified by Exome Sequencing Are Associated with Autism Susceptibility. Hum. Mutat. 2012, 33, 1635-1638. [CrossRef] [PubMed]

93. Shi, L.; Zhang, X.; Golhar, R.; Otieno, F.G.; He, M.; Hou, C.; Kim, C.; Keating, B.; Lyon, G.J.; Wang, K.; et al. Whole-Genome Sequencing in an Autism Multiplex Family. Mol. Autism 2013, 4, 8. [CrossRef] [PubMed]

94. Iqbal, Z.; Vandeweyer, G.; van der Voet, M.; Waryah, A.M.; Zahoor, M.Y.; Besseling, J.A.; Roca, L.T.; Vulto-van Silfhout, A.T.; Nijhof, B.; Kramer, J.M.; et al. Homozygous and Heterozygous Disruptions of ANK3: At the Crossroads of Neurodevelopmental and Psychiatric Disorders. Hum. Mol. Genet. 2013, 22, 1960-1970. [CrossRef]

95. Karaca, E.; Harel, T.; Pehlivan, D.; Jhangiani, S.N.; Gambin, T.; Coban Akdemir, Z.; Gonzaga-Jauregui, C.; Erdin, S.; Bayram, Y.; Campbell, I.M.; et al. Genes That Affect Brain Structure and Function Identified by Rare Variant Analyses of Mendelian Neurologic Disease. Neuron 2015, 88, 499-513. [CrossRef] [PubMed]

96. Kloth, K.; Denecke, J.; Hempel, M.; Johannsen, J.; Strom, T.M.; Kubisch, C.; Lessel, D. First De Novo ANK3 Nonsense Mutation in a Boy with Intellectual Disability, Speech Impairment and Autistic Features. Eur. J. Med. Genet. 2017, 60, 494-498. [CrossRef]

97. Hu, H.; Kahrizi, K.; Musante, L.; Fattahi, Z.; Herwig, R.; Hosseini, M.; Oppitz, C.; Abedini, S.S.; Suckow, V.; Larti, F.; et al. Genetics of Intellectual Disability in Consanguineous Families. Mol. Psychiatry 2019, 24, 1027-1039. [CrossRef]

98. Zhu, X.; Petrovski, S.; Xie, P.; Ruzzo, E.K.; Lu, Y.F.; McSweeney, K.M.; Ben-Zeev, B.; Nissenkorn, A.; Anikster, Y.; Oz-Levi, D.; et al. Whole-Exome Sequencing in Undiagnosed Genetic Diseases: Interpreting 119 Trios. Genet. Med. 2015, 17, 774-781. [CrossRef]

99. Yang, R.; Walder-Christensen, K.K.; Lalani, S.; Yan, H.; García-Prieto, I.D.; Álvarez, S.; Fernández-Jaén, A.; Speltz, L.; Jiang, Y.H.; Bennett, V. Neurodevelopmental Mutation of Giant Ankyrin-G Disrupts a Core Mechanism for Axon Initial Segment Assembly. Proc. Natl. Acad. Sci. USA 2019, 116, 19717-19726. [CrossRef] [PubMed]

100. Saitsu, H.; Tohyama, J.; Kumada, T.; Egawa, K.; Hamada, K.; Okada, I.; Mizuguchi, T.; Osaka, H.; Miyata, R.; Furukawa, T.; et al. Dominant-Negative Mutations in Alpha-II Spectrin Cause West Syndrome with Severe Cerebral Hypomyelination, Spastic Quadriplegia, and Developmental Delay. Am. J. Hum. Genet. 2010, 86, 881-891. [CrossRef]

101. Hamdan, F.F.; Saitsu, H.; Nishiyama, K.; Gauthier, J.; Dobrzeniecka, S.; Spiegelman, D.; Lacaille, J.C.; Décarie, J.C.; Matsumoto, N.; Rouleau, G.A.; et al. Identification of a Novel in-Frame De Novo Mutation in SPTAN1 in Intellectual Disability and Pontocerebellar Atrophy. Eur. J. Hum. Genet. 2012, 20, 796-800. [CrossRef] [PubMed]

102. Nonoda, Y.; Saito, Y.; Nagai, S.; Sasaki, M.; Iwasaki, T.; Matsumoto, N.; Ishii, M.; Saitsu, H. Progressive Diffuse Brain Atrophy in West Syndrome with Marked Hypomyelination Due to SPTAN1 Gene Mutation. Brain Dev. 2013, 35, 280-283. [CrossRef] [PubMed]

103. Syrbe, S.; Harms, F.L.; Parrini, E.; Montomoli, M.; Mütze, U.; Helbig, K.L.; Polster, T.; Albrecht, B.; Bernbeck, U.; van Binsbergen, E.; et al. Delineating SPTAN1 Associated Phenotypes: From Isolated Epilepsy to Encephalopathy with Progressive Brain Atrophy. Brain 2017, 140, 2322-2336. [CrossRef]

104. Ream, M.A.; Mikati, M.A. Clinical Utility of Genetic Testing in Pediatric Drug-Resistant Epilepsy: A Pilot Study. Epilepsy Behav. 2014, 37, 241-248. [CrossRef]

105. Beijer, D.; Deconinck, T.; De Bleecker, J.L.; Dotti, M.T.; Malandrini, A.; Urtizberea, J.A.; Zulaica, M.; López de Munain, A.; Asselbergh, B.; De Jonghe, P.; et al. Nonsense Mutations in Alpha-II Spectrin in Three Families with Juvenile Onset Hereditary Motor Neuropathy. Brain 2019, 142, 2605-2616. [CrossRef]

106. Dong, H.L.; Chen, L.; Wu, Z.Y. A Novel De Novo SPTAN1 Nonsense Variant Causes Hereditary Motor Neuropathy in a Chinese Family. Brain 2021, 144, e11. [CrossRef] [PubMed]

107. Knierim, E.; Gill, E.; Seifert, F.; Morales-Gonzalez, S.; Unudurthi, S.D.; Hund, T.J.; Stenzel, W.; Schuelke, M. A Recessive Mutation in Beta-IV-Spectrin (SPTBN4) Associates with Congenital Myopathy, Neuropathy, and Central Deafness. Hum. Genet. 2017, 136, 903-910. [CrossRef] [PubMed]

108. Anazi, S.; Maddirevula, S.; Salpietro, V.; Asi, Y.T.; Alsahli, S.; Alhashem, A.; Shamseldin, H.E.; AlZahrani, F.; Patel, N.; Ibrahim, N.; et al. Expanding the Genetic Heterogeneity of Intellectual Disability. Hum. Genet. 2017, 136, 1419-1429. [CrossRef] [PubMed]

109. Wang, C.C.; Ortiz-González, X.R.; Yum, S.W.; Gill, S.M.; White, A.; Kelter, E.; Seaver, L.H.; Lee, S.; Wiley, G.; Gaffney, P.M.; et al. betaIV Spectrinopathies Cause Profound Intellectual Disability, Congenital Hypotonia, and Motor Axonal Neuropathy. Am. J. Hum. Genet. 2018, 102, 1158-1168. [CrossRef] [PubMed]

110. Pehlivan, D.; Bayram, Y.; Gunes, N.; Coban Akdemir, Z.; Shukla, A.; Bierhals, T.; Tabakci, B.; Sahin, Y.; Gezdirici, A.; Fatih, J.M.; et al. The Genomics of Arthrogryposis, a Complex Trait: Candidate Genes and Further Evidence for Oligogenic Inheritance. Am. J. Hum. Genet. 2019, 105, 132-150. [CrossRef]

111. Monies, D.; Abouelhoda, M.; Assoum, M.; Moghrabi, N.; Rafiullah, R.; Almontashiri, N.; Alowain, M.; Alzaidan, H.; Alsayed, M.; Subhani, S.; et al. Lessons Learned from Large-Scale, First-Tier Clinical Exome Sequencing in a Highly Consanguineous Population. Am. J. Hum. Genet. 2019, 104, 1182-1201. [CrossRef]

112. Häusler, M.G.; Begemann, M.; Lidov, H.G.; Kurth, I.; Darras, B.T.; Elbracht, M. A Novel Homozygous Splice-Site Mutation in the SPTBN4 Gene Causes Axonal Neuropathy without Intellectual Disability. Eur. J. Med. Genet. 2020, 63, 103826. [CrossRef] [PubMed]

113. Ortiz-Gonzalez, X.; Wierenga, K. SPTBN4 Disorder. Available online: https://www.ncbi.nlm.nih.gov/books/NBK559435/ ?report=classic (accessed on 12 August 2021).

114. Kaphzan, H.; Buffington, S.A.; Jung, J.I.; Rasband, M.N.; Klann, E. Alterations in Intrinsic Membrane Properties and the Axon Initial Segment in a Mouse Model of Angelman Syndrome. J. Neurosci. 2011, 31, 17637-17648. [CrossRef] [PubMed] 
115. Booker, S.A.; Simoes de Oliveira, L.; Anstey, N.J.; Kozic, Z.; Dando, O.R.; Jackson, A.D.; Baxter, P.S.; Isom, L.L.; Sherman, D.L.; Hardingham, G.E.; et al. Input-Output Relationship of CA1 Pyramidal Neurons Reveals Intact Homeostatic Mechanisms in a Mouse Model of Fragile X Syndrome. Cell Rep. 2020, 32, 107988. [CrossRef] [PubMed]

116. Hong, T.; Falcone, C.; Dufour, B.; Amina, S.; Castro, R.P.; Regalado, J.; Pearson, W.; Noctor, S.C.; Martínez-Cerdeño, V. GABAARalpha2 Is Decreased in the Axon Initial Segment of Pyramidal Cells in Specific Areas of the Prefrontal Cortex in Autism. Neuroscience 2020, 437, 76-86. [CrossRef]

117. Ariza, J.; Rogers, H.; Hashemi, E.; Noctor, S.C.; Martínez-Cerdeño, V. The Number of Chandelier and Basket Cells Are Differentially Decreased in Prefrontal Cortex in Autism. Cereb. Cortex 2018, 28, 411-420. [CrossRef]

118. Tian, T.; Quintana-Urzainqui, I.; Kozić, Z.; Pratt, T.; Price, D.J. Pax6 Regulates the Morphological and Electrophysiological Development of Mouse Prethalamic Neurons. bioRxiv 2021. [CrossRef]

119. Tang, X.; Jaenisch, R.; Sur, M. The Role of GABAergic Signalling in Neurodevelopmental Disorders. Nat. Rev. Neurosci. 2021, 22, 290-307. [CrossRef]

120. Chen, R.; Gore, F.; Nguyen, Q.A.; Ramakrishnan, C.; Patel, S.; Kim, S.H.; Raffiee, M.; Kim, Y.S.; Hsueh, B.; Krook-Magnusson, E.; et al. Deep Brain Optogenetics without Intracranial Surgery. Nat. Biotechnol. 2021, 39, 161-164. [CrossRef] [PubMed]

121. Gong, X.; Mendoza-Halliday, D.; Ting, J.T.; Kaiser, T.; Sun, X.; Bastos, A.M.; Wimmer, R.D.; Guo, B.; Chen, Q.; Zhou, Y.; et al. An Ultra-Sensitive Step-Function Opsin for Minimally Invasive Optogenetic Stimulation in Mice and Macaques. Neuron 2020, 107, 38-51.e8. [CrossRef] 